\title{
Pelatihan Pengolahan Singkong Menjadi Keripik bagi Pemuda untuk Meningkatkan Kreatifitas di Masa Covid-19 di Desa Sukadana
}

\author{
Terasne $^{1}$, Tri Setianingsih ${ }^{2}$, Ahmad Hanan $^{3}$, Sri Sukarni $^{4}$, Baiq Zuhrotun Nafisah ${ }^{5}$ \\ terasne@ikipmataram.ac.id ${ }^{1}$, trisetianingsih@ikipmataram.ac.id ${ }^{2}$, \\ ahmadhanan@ikipmataram.ac.id ${ }^{3}$, srisukarni63@gmail.com ${ }^{4}$, \\ baiq.nafisah@gmail.com ${ }^{5}$ \\ 1,2,3,4,5 Universitas Pendidikan Mandalika (UNDIKMA)
}

\begin{abstract}
Article History:
Received: 14-06-2021

Revised: 17-07-2021

Accepted: 24-07-2021
\end{abstract}

Keywords : creativity, cassava, chips, covid-19, entrepreneurs.

\begin{abstract}
This Community Service Activity (PkM) aimed to improve skill (creativity) and increase the knowledge of Sukadana village youth to be more creative in their activities even at home during the Covid-19 period and create opportunities to become new entrepreneurs based on cassava processing of the Sukadana village community for youth and surrounding communities namely teachers and students through training in processing cassava into "Chips" or called "Keripik" which have high economic value and can be sold in the market. The methods used in PKM activities are socialization, counseling, training and mentoring. While the activity procedures are, socialization and preparation of activities, intensive training on processing cassava products into chips, monitoring and evaluation (activity response and product feasibility testing), and product marketing. The result of this activity is the processed product of "Chips" in Sukadana village. The results of PKM activities generally include several components as follows: 1) The success of meeting the target number of training participants, 2) The achievement of training objectives, 3) The achievement of the planned material targets, 4) The ability of participants in mastering the material. The achievement of the training objectives in general was very smooth and good, all materials could be delivered in detail. The results of the training of the participants that the quality of the chips that have been produced has met the savory taste, it can be concluded that the purpose of this activity has been well achieved.
\end{abstract}

\section{Pendahuluan}

Desa Sukadana terletak di Kecamatan Bayan Kabupaten Lombok Utara. Desa ini terdiridari 11 dusun diantaranya dusun Sukadana, BatuTepak, Karang Gending, Labang Kara, Lendang Jeliti, Lokok Buak, Lokok Kengkang, Ruak Bangket, Segenter, Teluk, Lendang Gagak. Adapun batas desa Sukadana yaitu: Sebelah Utara berbatasan dengan Laut Jawa, sebelah Barat berbatasan dengan desa Persiapan Andalan, SebelahTimur berbatasan dengan Desa Anyar dan Desa Senaru, dan Sebelah Selatan berbatasan dengan desa Persiapan Batu Rakit dan jarak kecamatan Bayan dari ibu kota kabupaten sekitar 60 km. Sudirman,B.(2014) menerangkan bahwa secara umum letak geografis desa Sukadana mempunyai areal dataran rendah dan areal dataran tinggi seluas 365 ha.Pada areal dataran 
tinggi dan rendah dapat ditanami padi, kacang - kacangan, palawaija, danumbi -umbian seperti ubi talas, ubi jalar, singkong. Sesuai dengan pendapatnya Jamal, dkk. (2018) menjelaskan bahwa secara geologis jenis tanah pada dataran rendah adalah lembung pasir dan yang dapat tumbuh adalah tanaman yang berumur pendek seperti palawija, sayurmayur, umbi-umbian seperti ubi talas, ubi jalar, singkong dan lain-lain. Singkong adalah salah satu jenis umbi-umbian yang sangat sering dan mudah ditemukan dimana-mana karena pada dasarnya tanaman ini sangat mudah tumbuh begitu saja.

Di desa Sukadana, tanaman ini cukup mudah untuk mencarinya terutama di pekarangan rumah dan lahan warga danse lamaini ketersediaan singkong melimpah hasil pertanian masyarakat. Masyarakat desa Sukadana biasanya singkong dianggap sebagai tanaman biasa yang hanya untuk memenuhi kebutuhan rumah tangga sehari-hari sehingga singkong belum dimamanfaatkan menjadi olahan makanan alternative seperti keripik atau olahan bahan makanan lainnya. Bagi masyarakat desa Sukadana, singkong biasanya diolah ketika mengadakan kegiatan bersama dengan cara direbus, dibakar, dan digoreng. Akan tetapi apabila diolah menjadi beberapa makanan seperti keripik dengan cita rasa yang enak dan dikemas dengan elegan akan bernilai ekonomi yang dapat menguntungkan dan menjadi peluang usaha untuk pemuda desa Sukadana kecamatan Bayan. Menurut Suprapti (2005), mengatakan bahwa singkong dapat diproses menjadi berbagai macam produk jadi yang dapat langsung dikonsumsi dan produk setengah jadi yang merupakan produk antara. Produk antara tersebut perlu diproses lanjut terlebih dahulu menjadi produk-produk tertentu baru kemudian dapat dikonsumsi.

Hal ini dapat diketahui berdasarakan hasil wawancara sekaligus sebagai survei awal pada tanggal 5 Februari 2021 oleh ketua tim bersama bapak Mistari selaku kepala dusun Lendang Gagak dimana kegiatan pengabdian ini dilaksanakan, beliau menjelaskan lebih rinci bahwa secara topogarafi desa ini merupakan daerah berbukit yang terdiri dari sawah irigasi $1 \frac{1}{2}$ teknis 190 ha, sawah tadah hujan 211 ha, tanah ladang 998,15 ha, permukiman 15,987 ha, tanah perkebunan rakyat 99,8 ha. Selain itu, masyarakat desa Sukadana sebagian besar adalah petani dan buruh tani, nelayan, sebagian kecil pegawai negeri dan kegiatan usaha lainnya seperti berjulan di toko-toko. Masyarakat desa Sukadana biasanya menanam padi musim penghujan saja dan pada musim panas mereka menanam kacangkacangan pada areal dataran rendah sedangkan pada areal dataran tinggi mereka menanam umbi-umbian salah satunya singkong. Akan tetapi singkong tidak dijadikan makanan alternatif lain atau sebagai pengganti beras.Tanaman ini dibiarkan begitu saja tumbuh di lahan dan di pekarangan mereka masing-masing.

Menurut pendapat Ratnah, dkk. (2018) menjelaskan bahwa singkong merupakan hasil pertanian yang jumlahnya berlimpah dan perlu alternatif lain dalam pemanfaatannya untuk menunjang program ketahanan pangan sebagai pengganti beras. Masyarakat desa https://journal.universitasbumigora.ac.id/index.php/ADMA 
Sukadana lebih memilih menanam umbi-umbian seperti singkong daripada tanaman umbian lainnya karena selain buah, daun, dan batang singkong sangat berguna dijadikan bahan pakan ternak terutama yang tumbuh dengan sendirinya di lahan dan di pekarangan mereka masing-masing. Rukmana dan Yuniarsih, (2001) mengatakan bahwa singkong sangat berarti dalam usaha penganekaragaman pangan penduduk, dan berfungsi sebagai bahan baku industri makanan sertabahan pakan ternak seperti buah, kulit, batang, dan daunnya.

Menurut bapak Mudjitahid selaku ketua pemuda desa Sukadana menjelaskan bahwa masyarakat desa Sukadana saatCovid-19 seperti sekarang ini lebih banyak beraktifitas dirumahmereka masing-masing dikarenakan adanya kekhawatiran terjangkit virus. Keadaan seperti ini juga dialami oleh guru dan siswa yang melaksanakan pembelajaran tatap muka disekolah. Dimana di desa Sukadana terdapat ada beberapa sekolah dengan jumlah 32 buah pendidikan formal dengan perincian 1 buah TK, 28 buah SD, 2 buah SMP, dan 1 buah SMU, serta 2 buah pondok pesantren yakni Al-Mujahidin dan Nurul Bayan. Sejalan dengan Keputusan Pemerintah yang memindahkan proses pembelajaraan dari sekolah menjadi di rumah akibatnya guru, siswa dan orang tuamengalami kekhawatiran akan bahaya virus tersebut sehingga mereka lebih memilih beraktifitas di rumah. Hal ini juga dipicu oleh belum adanya kesiapan dari para guru dan terutama kepala sekolah selaku pimpinan untuk melaksanakan proses pendidikan secara tatap muka dan bahkan daring atau online. Wesis (2009) pada Terasne, dkk. (2020) menerangkan bahwa belajar dalam rumah termasuk dalam pembelajaran jarak jauh yang dikenal dengan blended learning meskipun siswa tidak berkumpul disatu tempat secara rutin untuk menerima pelajaran secara langsung dari instruktur. Ditambahkan oleh Blau dan Caspi (2009) menerangkan bahwa pembelajaran blended learning adalah gabungan anatara pembelajaran jarak jauh dengan pembelajaran menggunakan teknologi.

Oleh kerena demikian, bapak Mudjitahid mengajak beberapa orang pemuda desa Sukadana membuat singkong yang telah tersedia di lahan mereka. Keripik singkong hasil olahan diberikan garam dan warna kuning alami dan masih menggunakan alat yang sangat sederhana. Dalam memproduksi keripik singkong tidak dapat mencapai jumlah banyak karena kurangnya tenaga kerja terampil di desa Sukadana untuk mengolah singkong menjadi olahan yang bernilai ekonomi sehingga tidak memenuhi permintaan pasar. Langkah kreatif ini meginsfirasi tim pengabdian menjadikan mitra untuk mengolah singkong tersebut menjadi sesuatu yang bernilai ekonomi.

Maka dari itu, Pengabdian Kepada Masyarakat (PkM) ini menjalin mitra bersama pemuda desa Sukadana dan masyarakat sekitar yaitu beberapa orang guru dan beberapa orang siswa untuk mengadakan kegiatan yang dikemas dalam bentuk pelatihan pengolahan singkong menjadi keripik bagi pemuda untuk meningkatkan kreatifitas dimasa Covid-19di desa Sukadana, kecamatan Bayan.

https://journal.universitasbumigora.ac.id/index.php/ADMA 


\section{Metode}

Pada pelaksanaan program kegiatan Pengabdian Kepada Masyarakat (PkM) ini, yang menjadi target kegiatannya adalah pemuda Sukadana, masyarakat sekitar yaitu guru dan siswa yang saat ini beraktifitas dirumahsajaakibat covid-19. Sasaran rekrutmen kegiatan ini bekerjasama dengan mitra (pemudadesa Sukadana dan masyarakat sekitar yaitu guru dan siswa) yang memfasilitasi tempat pelaksanaan kegiatan.

Metode yang digunakan dalam pelaksanaan kegiatan ini yaitu:

1. Sosialisasi: bertujuan untuk memberikan informasi dan arahan kepada mitra dan calon peserta kegiatan (yang saat ini beraktifitas dirumah saja akibat covid-19) sebagai bentuk penguatan komitment untuk mensukseskan kegiatan PKM ini.

2. Persiapan Kegiatan: bertujuan untuk mengindetifikasi dan menyiapkan segala kebutuhan untuk pelaksanaan kegiatan.

3. Penyuluhan: bertujuan untuk memberikan pengetahuan dan informasi mengenai cara pengolahan singkong menjadi keripik dan peluang menjadi wirausaha sehingga termotivasi untuk membentuk kelompok usaha baru.

4. Pelatihan: merupakan kegiatan inti untuk memberikan materi dan praktek pengolahan singkongmenjadi keripik yang diberi merk Keripik Fantasi, pada proses pelatihan akan dilakukan monitoring dan evaluasi untuk mengetahui ketercapian dan proses kegiatan yang masih kurang optimal.

5. Pendampingan: bertujuan untuk mendampingi mitra dan sasaran utama kegiatan dalam upaya menjaga keberlanjutan hasil kegiatan, selain itu pendampingan dalam membentuk manajemen usaha dan pemasaran produk. Program kegiatan Pengabdian Kepada Masyarakat (PkM) ini, menggunakan pendekatan terpadu melalui pelaksanan pelatihan yang standar dan terukur dengan menganalisis kebutuhan pelatihan, perencanaan pelatihan, penyusunan bahan pelatihan, pelaksanaan pelatihan, dan evaluasi pelatihan. Oleh Mujiman, (2009) mengatakan bahwa dengan program pendampingan pasca pelatihan sebagai bentuk peningkatan produk dan keberhasilan program kegiatan pengabdian. Prosedur kerja program kegiatan Pengabdian Kepada Masyarakat (PkM) ini menggunakan siklus pelatihan dengan melakukan improvisasi.

Adapun deskripsi prosedur kerja program PkM ini yaitu:

1. Sosialisasi program yang merupakan hal yang paling mendasar dari analisis kebutuhan. Sosialisasi program ini dilaksanakan dengan mengadakan pertemuan dengan mitra dan calon peserta kegiatan untuk menyampaikan persepsi dan memperkuat komitmen terhadap penyelenggaraan program. Pada sosialisasi ini juga dilakukan analisis kebutuhan pelatihan dengan melakukan indentifikasi sumber daya yang dibutuhkan untuk pelaksanaan pelatihan pengolahan singkong menjadi keripik. 
2. Persiapan program merupakan bagian dari perencanaan pelatihan. Persiapan program ini dilakukan secara bersama dengan melibatkan mitra dan calon peserta kegiatan untuk menyusun jadwal pelatihan (waktu, lokasi, dan susunan kegiatan pelatihan).

3. Penyusunan bahan pelatihan yang meliputi penyusunan rancangan pelatihan, penyedian peralatan dan penyediaan bahan baku pelatihan.

4. Pelaksanaan pelatihan, dilakukan secara intensif meliputi 3 (tiga) tahapan yakni:

a. Pelatihan tahap pertama; fokus pada penyampaian materi (teori) mengenai pemanfaatan dan pengolahan singkong menjadi keripik, serta materi motivasi menjadi wirausaha yang sukses. Penyampaian materi ini dilakukan selama 3 hari.

b. Pelatihan tahap kedua; fokus pada penyampaian materi manajemen usaha agar peserta pelatihan memperoleh pengetahuan dan ketrampilan dalam mengelola usaha yang akan dirintis. Penyampaian materi tahap kedua inidilakukan selama 3 hari. Pelatihan tahap ketiga; fokus pada praktek langsung cara pengolahan singkong menjadi keripik dan teknik pengemasan produk. Dalam proses pelatihan ini juga akan dirintis kelompok usaha bersama baru. Proses pelatihan dilakukan selama 2 bulan secara terjdawal dengan melibatkan peserta pelatihan dalam penentuan jadwal pelatihan yang dimaksud.

c. Evaluasi Pelatihan, dilakukan untuk mengetahui pencapaian tujuan pelaksanaan pelatihan. Evaluasi pelatihan ini menggunakan instrumen angket, observasi dan wawancara. Angket digunakan untuk menegetahui respon (tanggapan) peserta terhadap kegiatan pelatihan. Observasi digunakan untuk mengamati kemampuan peserta dalam mempraktekkan materi pelatihan, dan wawancara digunakan untuk mendukung data evaluasi lainnya. Kegiatan evaluasi ini dibandingkan dengan indikator keberhasilan pelatihan yang sudah ditentukan sebelumnya. Indikator keberhasilan pelatihan ini yaitu:

1) Lebih dari $75 \%$ peserta hadir

2) Lebih dari $75 \%$ peserta menyatakan kegiatan pelatihan ini bermanfaat

3) Lebih dari $75 \%$ peserta pelatihan memiliki motivasi menjadi wirausaha baru dibidang pengolahan singkong menjadi Keripik

4) Terbentuknya kelompok usaha bersama dibidang pengolahan Keripik. Dalam evaluasi pelatihan ini akan dilakukan uji kelayakan produk yang dihasilkan. Selain itu akan dilakukan uji coba pada warga masyarakat desa Sukadana untuk mengetahui respon atau tanggapan terhadap hasil produk.

d. Pendampingan, dilakukan untuk mendampingi peserta pelatihan dan mitra dalam manajemen usaha serta pemasaran produk. Partisipasi mitra dalam proses pelaksanaan program PKM ini adalah menyediakan bahan baku, menyediakan tempat pelatihan, memobilisasi peserta agar hadir dalam pelaksanaan pelatihan 
pengolahan singkong menjadi keripik serta menyediakan alat-alat pendukung lainnya yang diperlukan dalam pelatihan.

Alat :

1) Pisau pemotong

2) Nampan untuk penjemuran

3) Kompor

4) Penggorengan (wajan)

5) Wadah (ember)

6) Panci

Bahan :

1) Singkong/kukus/ketam tipis

2) Garam

3) Daun kunyit iris

4) Daun jeruk iris

5) Gula merah

Bumbu :

1) Kunyit

2) Bawang merah sedikit saja

3) Bawang putih

Berikut adalah cara mengolah keripik singkong; tumis bumbu yang sudah dihaluskan sampai harum dengan banyak minyak, berigaram/ penyedap. Aduk terus kemudian masukkan irisan daun jeruk dan kunyit beserta gulamerah, aduk terus sampai matang. Diamkan bumbu yang sudah ditumis sampai dingin lalu dicampurkan dengan singkong yang telah digoreng.

\section{Pembahasan}

Kegiatan Pengabdian Kepada Masyarakat (PkM) di desa Sukadana, Kecamatan Bayan ini dimulai sejak bulan Februari tahun 2021. Kegiatan ini diawali dengan tahap sosialisasi kepada masyarakat dan kordinasi dengan mitra, baik mitrasatu yaitu pemuda dan mitra dua yaitu masyarakat sekitar, guru dan siswa. Puncak kegiatan dilaksanakan padahari Sabtu dan Minggu tanggal 3 dan 4 April 2021. Pada hari pertama pemuda desa Sukadana dibekali dengan materi tentang berwira usaha dan materi tentang nilai gizi yang terkandung dalam singkong, sedangkan pada hari kedua dilanjutkan materi tentang pembuatan keripik singkong sekaligus praktik langsung oleh peserta. Dari serangkaian kegiatan pengabdian ini tidak terlepas dari kendala yang dihadapi antara lain: 
1) Masih kurang disiplinnya untuk hadir tepat waktu dalam mengikuti kegiatan serta banyak dianatara peserta tidak menggunakan masker dengan alasan malas mengenakan masker terutama ibu-ibu.

2) Beberapa peserta belum terampil dalam mengiris singkong dengan hasil irisan yang tips.

3) Masih terkendala untuk mendapatkan alat pengiris dan pelekat plastik elektrik yang modern.

Pelaksanaan kegiatan pengabdian kepada masyarakat dapat berjalan lancar, antusias dan semangat pemuda yang sangat luar biasa. Dari hasil kegiatan pelatihan tersebut memberikan dampak yang sangat signifikan, hal ini terlihat dari pengolahan singkong menjadi keripik yang langsung diparktekan sendiri oleh pemuda tanpa dipandu lagi oleh tim pelaksana PKM. Produksi perdana keripik singkong ini dilakukan padatanggal 6April2021. Apaun proses dan hasil olahan singkong dapat dilihat padagambar berikut: 1. Singkong diambil dari lahan, 2. kulit Singkong dikupas atau dibersihkan menggunkan air setelah itu diiris 3. Singkong digoreng dan 4 Singkong dikemas kedalam plastik kecil.

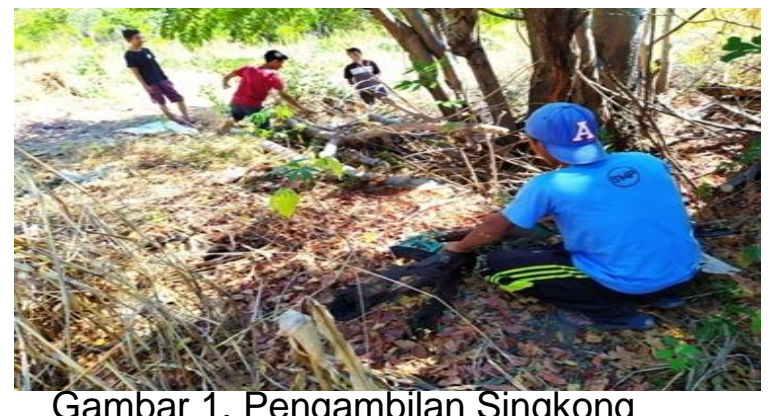

Gambar 1. Pengambilan Singkong

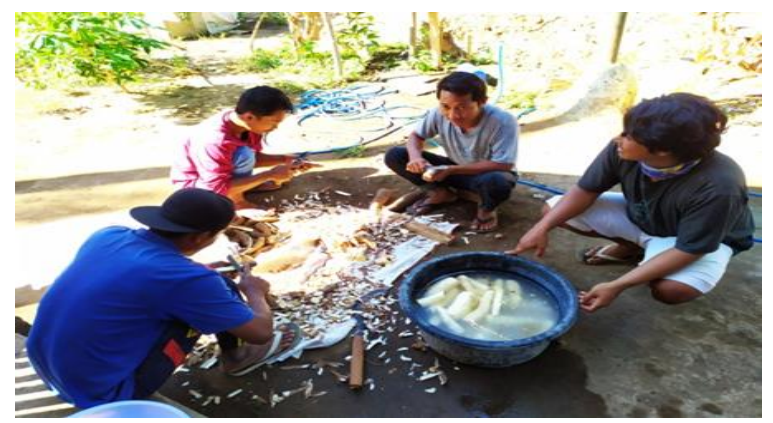

Gambar 2. Pengupasan singkong

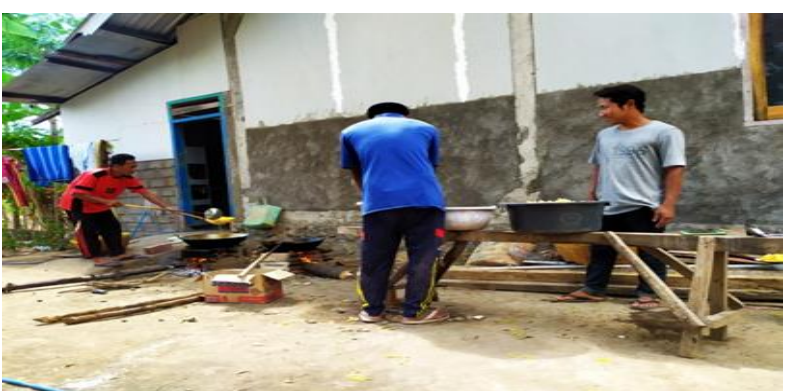

Gambar 3. Penggorengan keripik 


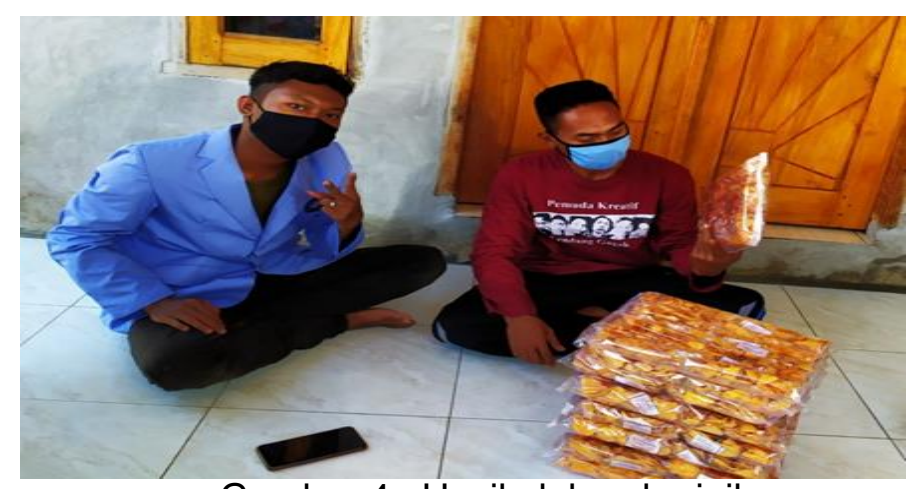

Gambar 4. Hasil olahan keripik

Program Pengabdian Kepada Masyarakat (PkM) yang sudah dilaksanakan ini diharapkan dapat meningkatkan keterampilan (kreatifitas) dan menambah pengetahuan pemuda desa Sukadan menjadi lebih kreatif beraktifitas meskipun dirumah saja dan dapat menambah nilai jual yang tinggi dari hasil perkebunan singkong masyarakat. Pemuda dan masyarakat sekitar terutama ibu rumahtangga, guru dan siswa juga memiliki penghasilan tambahan dimasa pandemi covid-19 seperti saat ini. Manfaat lain juga yang dapat diambil dari hasil kegiatan PkM ini adalah masyarakat desa Sukadana mampu mengolah hasil produk lokal (singkong) menjadi lebih modern dan tidak hanya terbatas pada olahan singkong goreng dan rebus dengan bumbu tradisional. Pelatihan ini juga didampingi oleh mitra yaitu pemuda desa Sukadana kecamatan Bayan selama kegiatan pelatihan berlangsung.

Hasil kegiatan PkM secara garisbesar mencakup beberapa komponen sebagai berikut: 1) Keberhasilan memenuhi target jumlah pesertapelatihan, 2) Ketercapaian tujuan pelatihan, 3) Ketercapaian target materi yang telah direncanakan, 4) Kemampuan peserta dalam penguasaan materi. Target peserta pelatihan seperti direncanakan sebelumnya adalah paling tidak 42 orang pemuda yaitu 2 orang sebagai perwakilan dari 11 dusun yang ada di desa Sukadana yang saat ini kreatifitasnya kurang akibat Covid-19.

Hasil pelatihan parapeserta yaitu kualitas keripik yang telah dihasilkan sudah memenuhi rasa yang gurih, maka dapat disimpulkan bahwa tujuan kegiatan ini sudah tercapai dengan baik darikegiatan pengabdian ini tentu menghasilkan luaran. Adapun luaran yang dicapai antara lain: Publikasipadajurnal ilmiah di Jurnal ADMA (Jurnal Pengabdian dan Pemberdayaan Masyarakat.

\section{Kesimpulan}

Program pelatihan pengolahan singkong menjadi keripik di desa Sukadana kecamatan Bayan dapat diselenggarakan dengan baik dan berjalan dengan lancar sesuai dengan rencana kegiatan yang telah disusun. Kegiatan ini mendapat sambutan sangat baik terbukti dengan keaktifan peserta mengikuti pelatihan dengan tidak meninggalkan tempat 
sebelum waktu pelatihan berakhir. Kegiatan ini juga tidak terlepas dari peran serta mitra 1 (pemuda desa Sukadana) dan mitra 2 (Masayarakat sekitar yaitu guru dan siswa) yang terus mendampingi selama kegiatan pelatihan berlangsung.

\section{Ucapan Terima Kasih}

Tim Pengabdian Kepada Masyarakat (PkM) mengucapkan terimakasih kepada: Bapak Mistari selaku kepala dusun Lendang Gagak sekaligus penanggung jawab kegiatan dan dusun Lendang Gagak sebagai tempat pelaksanaan kegiatan, Bapak Mudjitahid, S.Pd., selaku ketua pemuda desa Sukadana, dan Seluruh masyarakat desa Sukadana yang telah mempasiltasi kegiatan ini sejak awal sampai dengan akhir acara kegiatan PKM.

\section{Daftar Pustaka}

Blau dan Caspi (2009) pada Terasne, dkk (2020). Pelatihan Pemanfaatan google Classroom Sebgai Media Pembelajaran Alternatif pada Masa Covid-19 Bagi Guru: Sasambo Jurnal Abdimas (Journal of Community Service) 2 (3) 95-100

Jamal, dkk. (2018) Pengabdian Kepada Masyarakat berupa Pengolahan SingkongMenjadi Keripik Untuk Kelompok Petani Singkong.Prosiding Seminar Hasil Pengabdian (SNP2M) 2018 (pp.309-313).

Mujiman, Haris, (2009). Manajemen Pelatihan Berbasis Belajar Mandiri.Yogyakarta:Pustaka Pelajar.

Ratnah, dkk. (2018). Pelatihan Pengolahan Ubi Kayu Menjadi "kripik balado" Di Desa Teke Kecamatan Palibelo Kabupaten Bima Nusa Tenggara Barat (NTB): Jurnal Pendidikan dan Pengabdian Masyarakat 1 (3) 195-200. e-ISSN. 2614-7939) (p-ISSN. 2614-7947)Vol. 1 No. 2 , Agustus 2018 pp.295-200.

Rukmana, R. dan Yuniarsih, Y. 2001. Aneka Olahan Ubi Kayu. Yogyakarta: Kanisius.

Suprapti, L. (2005). Tepung Tapioka Pembuatan dan Pemanfaatan. Yogyakarta: Kanisius.

Sudirman, Bahri (2014). Studi Sejarah Budaya Lombok, (Lombok: pusat studi dan kajian budaya prov. NTB, 2014).

Wesis (2009) pada Terasne, dkk (2020). Pelatihan Pemanfaatan google Classroom Sebgai Media Pembelajaran Alternatif pada Masa Covid-19 Bagi Guru: Sasambo Jurnal Abdimas(Journal of Community Service) 2 (3) 95-100.

http;//journal-center.lipam.com/index.php/Sasambo_Abdimas/index e-ISSN 2636-519X//Vol.2 No.3 Oktober 2020, pp.95-100 
